\title{
KOMITMEN PARTAI POLITIK TERHADAP PENCALONANPEREMPUAN SEBAGAI ANGGOTA LEGISLATIF DALAM UPAYA REALISASI UNDANG-UNDANG NO. 12 TH. 2003 DI PEKANBARU
}

\author{
Sofia Hardani
}

\begin{abstract}
The involvement of women in formal politics in Indonesia began to be taken into account since the enactment of the Electoral Law No. 12 In 2003, on the General Election. In Act specified 30\% representation of women from all political parties in the parliamentary candidates in national and local level. In Riau Province, the representation of women in parliament has increased. but have not been able to meet the $30 \%$ quota for women. This is due to the attitude of the political parties have tended masculine. Undertake research to uncover the commitment of political parties to the nomination of women as members of the legislature in an attempt realization of law no. 12 of 2003 in the province of Riau. This study is a qualitative study, obtained by interview and observation to the board of DPD Golkar, PAN, PKS and the female candidates of political parties elected to the Legislative Council Pekanbaru period 2009-2014. The findings show the phenomenon of "halfhearted" of the party leadership to implement article 65, paragraph 1 of Law No. 12 in 2003 and are not genderresponsive policies, most party leaders still view women as "second class citizens" who do not deserve to sit in the first sequence number representing the party.
\end{abstract}

Keywords:political party, gender, commitment, and the representation of women

Abstrak: Keterlibatan perempuan dalam politik formal di Indonesia mulai diperhitungkan sejak diundangkannya Undang-Undang Pemilu No. 12 tahun 2003, tentang Pemilihan Umum. ditetapkan 30\% keterwakilan perempuan dari seluruh calon partai politik pada parlemen di tingkat nasional maupun lokal. Di Provinsi Riau, keterwakilan perempuan di DPRD mengalami peningkatan. tetapi belum dapat memenuhi quota $30 \%$ untuk perempuan. Hal ini disebabkan sikap politik partai yang selama ini cenderung maskulin. Perlu dilakukan penelitian untuk mengungkap komitmen partai politik terhadap pencalonan perempuan sebagai anggota legislatif dalam upaya realisasi undang-undang no. 12 tahun 2003 di provinsi Riau.Penelitian ini merupakan penelitian kualitatif, diperoleh dengan wawancara dan observasi kepada pengurus DPD Partai Golkar, PAN, PKS dan Para caleg perempuan dari partai politik yang terpilih menjadi anggota legislatifDPRD Kota Pekanbaru periode 2009-2014. Temuan penelitian menunjukkan adanya fenomena "separo hati" dari pimpinan partai untuk mengimplementasikan pasal 65 ayat 1 UU No. 12 tahun 2003 dan kebijakan yang tidak responsifjender, kebanyakan pemimpin partai masih tetap memandang perempuan sebagai "warga negara kelas dua" yang belum pantas untuk duduk di nomor urut pertama mewakili partainya.

Kata Kunci: partai politik, gender, komitmen, dan keterwakilan perempuan

\section{PENDAHULUAN}

Pemilu Legislatif adalah ajang perekrutan calon legislatif (caleg) yang diusung oleh berbagai partai politik untuk duduk sebagai anggota Dewan
Perwakilan Rakyat. Partai politik berperan penting dalam melakukan seleksi terhadap orang-orang yang berkualitas diusung menjadi calegnya, karena kualitas caleg akan berpengaruh 
kepada kualitas parlemen. Menurut Gabriel A. Almond dan Coleman ${ }^{1}$ fungsi partai politik yang ideal adalah berpartisipasi dalam sektor pemerintahan, dalam arti mendudukkan orangorangnya menjadi pejabat pemerintahan, sehingga dapat turut serta mengambil atau menentukan keputusan politik.

Keterwakilan kaum perempuan dalam lembaga legislatif akan sangat bergantung pada sistem pemilu di suatu negara, political will dari pemerintah, dan partai-partai politik yang ada. Sistem pemilu yang digunakan sangat besar pengaruhnya terhadap representasi perempuan dalam lembaga-lembaga legislatif. Sistem proporsional misalnya, akan memberi peluang bagi peningkatan representasi kaum perempuan, karena ia dapat mengakomodir kepentingan kelompok dan pluralisme dalam masyarakat, termasuk pluralisme gender. ${ }^{2}$

Undang-Undang Pemilu No. 12 tahun 2003, tentang Pemilihan Umum pasal 65 Ayat 1 yang menyebutkan, “Setiap partai politik peserta pemilu dapat mengajukan anggota DPR, DPRD, Provinsi dan DPRD Kabupaten/ Kota untuk setiap daerah pemilihan dengan memperhatikan Keterwakilan Perempuan sekurang-kurangnya 30\%", maka keterlibatan perempuan dalam politik formal di Indonesia mulai diperhitungkan, yaitu menetapkan jumlah 30\% dari seluruh calon partai politik pada parlemen di tingkat nasional maupun lokal. Aksi afirmasi tersebut antara lain disebabkan perempuan merupakan separuh jumlah penduduk Indonesia yang berperan penting dalam keberhasilan pembangunan. Bahkan, 53\% pemilih pada pemilu 2004 adalah perempuan. Namun keterwakilan mereka dalam politik formal jauh di bawah ambang ideal. $^{3}$

Di Provinsi Riau, keterwakilan perempuan di DPRD mengalami peningkatan. Pada periode 2004-2009, anggota DPRD perempuan berjumlah 6 (enam) orang dari 45 anggota, dan pada periode 2009-2014, jumlah mereka meningkat menjadi 7 (tujuh) orang dari 45 orang anggota. Meskipun angka tersebut meningkat, tetapi belum dapat memenuhi "tantangan" pemerintah dengan memberikan quota 30\% untuk perempuan. ${ }^{4}$ Sistem proporsional daftar terbuka sebagaimana yang diamanatkan oleh pasal 6 ayat 1 UU No. 12 tahun 2003 memungkinkan kaum perempuan untuk terpilih. Di sisi lain, pasal 67 ayat 1 Undang-Undang No. 12 tahun 2003 menyebutkan bahwa: "urutan nama calon anggota DPRD Provinsi, DPRD Kabupaten dan Kota untuk setiap daerah pemilihan disusun oleh KPU Provinsi, KPU Kabupaten dan Kota, berdasarkan nomor urut, jadi yang ditetapkan partai politik peserta pemilu sesuai dengan tingkatannya." Dengan demikian, jelaslah bahwa muaranya terletak pada kebijakan partai politik. 
Sofia Hardani: Komitmen Partai Politik Terhadap Pencalonan Perempuan sebagai Anggota Legislatif dalam Upaya Realisasi Undang-undang No.122 Th.2003 di Pekanbaru

Sikap politik individu maupun sikap politik partai yang selama ini cenderung maskulin disebabkan paham maskulin sosial dan "keagamaan" yang sudah melekat sangat mempengaruhi sikap partai dalam mendudukkan caleg perempuan di dalam partainya. Disamping itu, tidak gampang bagi partai politik untuk merekrut caleg perempuan yang "berkualitas" sebagai perwakilan partai.Disamping tanggung jawab moral partai dalam mengamanahkan caleg perempuan yang kredibel, terdapat pula persaingan perebutan kursi yang selama ini didominasi oleh kaum laki-laki.

Penelitian ini mengungkap komitmen partai politik terhadap pencalonan perempuan sebagai anggotalegislatif dalam upaya realisasi undang-undang no. 12 tahun 2003 di provinsi Riau dengan focus masalah padabagaimana proses seleksi calon anggota legislatif perempuan oleh partai-partaipolitik di Riau,apa prasyarat yang harus dimiliki oleh calon, apa kendala yang dihadapi partai dalam merekrut calon, bagaimana upaya partai politik dalam memenuhi quota undang-undang untuk caleg perempuan di parlemen.

Penelitian ini merupakan penelitian kualitatif dengan menjadikan pengurus DPD Partai Golkar, PAN, PKS kota Pekanbaru sebagai informan penelitian. Para caleg perempuan dari partai politik yang terpilih menjadi anggota legislatif DPRD Kota Pekanbaru periode 2009-2014 juga dijadikan sebagai informan penelitian ini.

Data primerdiperoleh dari partai, baik dari pengurus, anggota, maupun dokumen-dokumen partai yang terkait dengan seluruh proses seleksi calon anggota legislatif perempuan di Kota Pekanbaru, upaya dan sikap partai politik dalam memenuhi ketentuan undang-undang No. 12 tahun 2003. Data sekunder berhubungan dengan data penunjang berupa dokumentasi dan bahan-bahan lainnya yang dimiliki oleh partai yang dipilih.

Pengumpulan data dilakukan melalui teknik observasi dan wawancara.Untuk menguji kredibilitas data digunakan teknik triangulasi melalui strategi pengecekan derajat kepercayaan penemuan hasil penelitian dengan beberapa teknik pengumpulan data. ${ }^{5}$

Data dianalisa secara kualitatif. Model analasis yang digunakan adalah model interaktif seperti yang digambarkan oleh Miles dan Huberman ${ }^{6}$ sebagai berikut: (1) reduksi data; (2) penyajian data; (3) penarikan kesimpulan dan verifikasi; dan (4) merumuskan temuan.

\section{PEMBAHASAN}

Patai Politik di Indonesia: Pengertian, Tujuan, dan Fungsi

Menurut UU No.2 Tahun 2008 
tentang Partai Politik, Partai Politik (Parpol) adalah organisasi yang bersifat nasional dan dibentuk oleh sekelompok warga negara Indonesia secara sukarela atas dasar kesamaan kehendak dan citacita untuk memperjuangkan dan membela kepentingan politik anggota, masyarakat, bangsa dan negara, serta memelihara keutuhan Negara Kesatuan Republik Indonesia berdasarkan Pancasila dan UUD 1945.

Secara umum, Partai Politik adalah suatu organisasi yang disusun secara rapi dan stabil yang dibentuk oleh sekelompok orang secara sukarela dan mempunyai kesamaan kehendak, cita-cita, dan persamaan ideologi tertentu, dan berusaha untuk mencari dan mempertahankan kekuasaan melalui pemilihan umum untuk mewujudkan alternatif kebijakan atau program-program yang telah mereka susun. Atau secara umum, partai politik didefinisikan sebagai kumpulan orang yang membentuk sebuah partai yang bertujuan untuk merebut kekuasaan, mempertahankan kekuasaan dengan cara yang legitimasi melalui pemilihan umum. ${ }^{7}$

Menurut Miriam Budiardjo, partai politik adalah suatu kelompokyang terorganisir yang anggota-anggotanya mempunyai orientasi, nilai-nilai, dancita-cita yang sama. Tujuan kelompok ini ialah untuk memperoleh kekuasaan politik dan merebut kedudukan politik (biasanya) dengan cara konstitusional,untuk melaksankan kebijaksanaankebijaksanaan mereka. $^{8}$

Sigmund Neumann dalam bukunya Modern political Parties menyatakan bahwa partai politik, ${ }^{9}$ adalah organisasi artikulatif yang terdiri dari pelaku-pelaku politik yang aktif dalam masyarakat, yaitu mereka yang memusatkan perhatiannya pada menguasai kekuasaan pemerintahan dan yang bersaing untuk memperoleh dukungan rakyat, dengan beberapa kelompok lain yang mempunyai pandangan yang berbeda-beda.

Dengan demikian, partai politik merupakan perantara yang menghubungkan kekuatan-kekuatan dan ideologi sosial dengan lembaga-lembaga pemerintahan yang resmidan yang mengkaitkannya dengan aksi politik di dalam masyarakat politik yanglebih luas.Salah satu fungsi partai politik salah satunya adalah melakukan rekrutmen politik. Fungsi ini berkaitan erat dengan masalah seleksi kepemimpinan, baik kepemimpinan internal partai maupun kepemimpinan nasional yang lebih luas. Untuk kepentingan internalnya, setiap partai memerlukan dilakukannya kaderisasi karena setiap partai butuh kader-kader yang berkualitas, karena hanya dengankader yang demikian partai dapat menjadi partai yang mempunyai kesempatan lebih besar untuk mengembangkan diri.

Tujuan parpol adalah untuk 
Sofia Hardani: Komitmen Partai Politik Terhadap Pencalonan Perempuan sebagai Anggota Legislatif dalam Upaya Realisasi Undang-undang No.122 Th.2003 di Pekanbaru

mencari dan mempertahankan kekuasaan guna melaksanakan / mewujudkan program-program yang telah mereka susun sesuai dengan ideologi tertentu.

Adapun fungsi partai politik dapat digambarkan sebagai berikut:

a. Parpol sebagai sarana komunikasi politik

Komunikasi politik adalah proses penyampaian informasi politikdari pemerintah kepada masayarakatdan sebaliknya dari masyarakat kepada pemerintah. Parpol disini berfungsi untuk menyerap, menghimpun (mengolah, dan menyalurkan aspirasi politik masyarakat dalam merumuskan dan menetapakan suatu kebijakan. Contohnya adalah dilingkungan sekolah. OSIS itu ibarat Parpol. Jika ada aspirasi ataupun masalah yang dituntut siswa, misanya perbaikan fasilitas sekolah. Pada saat itu terjadi interaksi antara siswa dan OSIS menmbahas mengenai kurangnya fasilitas sekolah. Selanjutnya OSIS menyampaikan aspirasi/tuntutan siswa tadi kepada pihak sekolah. Interkasi antara siswa(masyarakat), OSIS (parpol) dan pihak sekolah (pemerintah), merupakan suatu komunikasi. OSIS sebgai suatu sarana komunikasi antara pihak siswa dan pihak sekolah. Dalam kehidupan politik suatu negara contoh tadi dapat diibaratkan para siswa itu masyarakat, OSIS itu Parpol, dan plhak sekolah itu Pemerintah.

b. Parpol sebagai sarana sosialisasi politik

Sosialisasi politik adalah proses pembentukan sikap dan orientasi politik mengenai suatu fenomena politik yang sedang dialami suatu negara. Proses ini disampaikan melalui pendidikan politik. Sosialisai yang dilakukan oleh parpol kepada masyarakat berupa pengenalan program-program dari partai tersebut. Dengan demikian, diharapkan kepada masyarakat agar dapat memilih parpol tersebut pada pemilihan umum. Contohnya adalah penyampaian program politik parpol pada acara kampanye menjelang pemilu. Hal tersebut merupakan salah satu fungsi papol sebagai sarana sarana sosialisasi politik.

c. Parpol sebagai sarana rekrutmen politik

Rekrutmen politik adalah proses seleksi dan pengangkatan seseorang atau kelompok untuk melaksanakan sejumlah peran dalam istem politik ataupun pemerintahan. Atau dapat dikatakan proses seleksi dan pengangkatan seseorang atau kelompok untuk menduduki suatu jabatan ataupun beberapa jabatan politik ataupun mewakili parpol itu dalam suatu bidang. Rekrutmen politik gunanya untuk mencari 
otang yang berbakat aatupun berkompeten untuk aktif dalam kegiatan politik.Contoh untuk hal ini ada pada komuikasi politik sebagaimana dikemukakan diatas, yaitu dilingkungan sekolah. OSIS akan mengganti ketua dan anggotanya karena masa jabatannya sudah habis. Proses OSIS tersubut dalam mencari ketua dan anggota OSIS baru merupakan suatu proses rekrutmen. Entah itu melalui penujukan dan penyeleksian ataupun melalui pemilihan. Sama hal nya dengan Papol, parpol akan mencari, menyeleksi, dan mengangkat suatu anggota baru untuk menduduki suatu jabatan partai atau di pemerintahan, ataupun untuk mewakili dalam pemilu.

d. Parpol sebagai sarana pengatur konflik

Pengatur konflik adalah mengendalikan suatu konflik (dalam hal ini adanya perbedaan pendapat atau pertikaian fisik) mengenai suatu kebijakan yang dilakukan oleh pemerintah. Pengendalian konflik ini dilakuakan dengan cara dialog, menampung dan selanjutnya membawa permasalahan tersebut kepada badan perwakilan rakyat(DPR/ DPRD/ Camat)untuk mendapatkan keputusan politik mengenai suatu permasalahan.Contoh untuk hal terakhir ini adalah bahwa di dalam masyarakat terjadi masalah mengenai naiknya harga BBM yang dilakukan oleh pemerintah. Banyak terjadi demo menentang kebijakan tersebut. Dalam kasus ini parpol sebagai salah satu perwakilan dalam masyarakat di badan pewakilan rakyat (DPR/DPRD), mengadakan dialog bersama masyarakat mengenai kenaikan harga BBM tersebut. Parpol dalam hal ini berfungsi sebagai mengendalikan konflik dengan cara menyampaikan kepada pemerintah guna mendapatkan suatu putusan yang bijak mengenai kenaikan harga BBM tersebut.

\section{Pentingnya Perempuan di Partai Politik}

Merujuk kepada hasil penelitian HegeSkjie $^{10}$, perempuan yang duduk di dalam partai dapat mengubah sudut pandang dan agenda partai, kebijakan yang dikeluarkannnya tidak menghasilkan kebijakan yang tumpang tindih karena perempuan mempunyai kepentingan dan sudut pandang politik yang berbeda dengan laki-laki, perhatian perempuan lebih dominan pada bidang sosial dan kesejahteraan, perlindungan lingkungan, perlucutan senjata, kebijakan kesetaraan, pendidikan/ kesehatan. Sementara perhatian politisi laki-laki lebih besar pada bidang ekonomi, transportasi, isu- 
isu energi, keamanan nasional, industri dan luar negeri.

Di samping hal-hal diatas, pengaruh kebijakan perempuan paling dominanadalah pada politik perlindungan secara bertahap yang ditujukan pada tanggungjawabnegara untukmemberikan kesempatan kepada perempuan menggabungkan kewajiban keibuan (motherhood) dengan hak kemerdekaan ekonomi. Hasil konkritnya adalah meningkatnya anggaran publik untuk pembiayaan perawatan anak-anak, pemilihan waktu kerja yang lebih lentur lewat penganggaran kerja/waktu, perluasan cuti orang tua dan menjamin hak ayah berbagi periode cuti, dan juga hak pensiun bagi pelayanan kerja yang tidak diupah.

\section{Dasar legalitas perempun di partai politik}

a. Hukum Positif

- UUD 1945 ps 28 ayat 2 (perlakuan khusus terhadap kelompok marginal)

- UU No. 68 th1958 (jaminan persamaan politik perempuan dan laki-laki)

- UU No. 7 th1984 (ratifikasi penghapusan segala bentuk diskriminasi terhadap perempuan.

- UU No. 39 th 1999 tentang HAM yang mengatur hak perempuan.

- Tap MPR RI No. VI/2002 (rekomendasi kpd presiden untu kuota $30 \%$ bagi perempuan di lembaga pengambil keputusan).

- Rekomendasi Dewan Sosial dan Ekonomi PBB agar Negara-negara anggota PBB dapat memenuhi target $30 \%$ perempuan di legislatif hingga th 2000. Bahkan sekarang telah diperbaharui menjadi 50\%, lima tahun stelah Konferensi Beijing.

- UU No. 12 tahun 2003 tentang Pemilihan Umum pasal 65 ayat 1: "Setiap partai politik peserta pemilu dapat mengajukan anggota DPR, DPRD, Provinsi dan DPRD Kabupaten/Kota untuk setiap daerah pemilihan dengan memperhatikan Keterwakilan Perempuan sekurang-kurangnya $30 \% "$

\section{b. Hukum Islam}

Di dalam Islam, hak politik perempuan mempunyai landasan yang cukup kuat, baik dari Al-Quran sebagai sumber hukum pertama dan utama, maupun sunnah Nabi serta praktekpraktek sahabat - meskipun sebagian kalangan menolak hal tersebut. Dalil yang dpat dijadikan argument adalah, antara lain sebagaimana Firman Allah SWT dalam surat at-Taubah ayat 71, yang artinya: "Dan orang-orang yang beriman, lelaki dan perempuan, sebahagian mereka (adalah) menjadi penolong bagi sebahagian yang lain, mereka menyuruh (mengerjakan) yang ma'ruf, mencegah dari yang munkar, mendirikan shalat, menunaikan zakat dan mereka taat pada 
Allah dan Rasul-Nya...."(QS.9:71)

Dalam surat Al-Mumtahanah ayat 12, Allah SWT menyeru kepada Nabi untuk mengakui hak politik perempuan: "Hai para Nabi, apabila datang kepadamu perempuan-perempuan yang beriman untuk mengadakan janji setia, bahwa mereka tiada akan menyekutukan Allah, tidak akan mencuri, tidak akan berzina, tidak akan membunuh anakanaknya, tidak akan berbuat dusta yang mereka ada-adakan antara tangan dan kaki mereka dan tidak akan mendurhakaimu dalam urusan yang baik, Maka terimalah janji setia mereka dan mohonkanlah ampunan kepada Allah untuk mereka. Sesungguhnya Allah Maha Pengampun lagi Maha Penyayang."(QS.60:12)

Sosok pribadi Ratu Balqis, penguasa Negeri Saba' yang bijaksana, dibanggakan Allah seperti termuat dalam Surat Al-Naml ayat 23: "Sesungguhnya Aku menjumpai seorang wanita yang memerintah mereka, dan dia dianugerahi segala sesuatu serta mempunyai singgasana yang besar.(QS, 27:23)

\section{HASIL PENELITIAN}

Penelitian yang dilakukan mengungkapkan hal-hal berikut:

a. Partai-partai peserta pemilu memiliki pandangan umum yang sama tentang keterlibatan perempuan di dunia politik jika dikaitkan dengan aturan Islam, Bahwa keterlibatan perempuan dalam dunia politik dari perspektif
Islam adalah sama dengan laki-laki dalam rangka amr ma'ruf nahiy munkar (At-Taubah: ayat 7).

Dalam pandangan partai, berpolitik dengan dilandasi etika dan nilai Islam adalah suatu bentuk ibadah. Oleh karena itu, keikutsertaan perempuan dalam parlemen diperbolehkan karena parlemen dipandang sebagai salah satu sarana untuk amr ma'ruf nahiy munkar terhadap pelaksanaan Negara dan pemerintahan demi kepentingan umat.

b. Seleksi calon legislatif perempuan yang dilakukan oleh partai-partai politik memiliki mekanisme yang variatif, dan tergantung kepada kebijakan partai itu sendiri. Akan tetapi, dalam beberapa indikator yang dijadikan sebagai dasar pertimbangan, dalam menentukan calon legislatif perempuan terdapat beberapa hal yang sama, seperti tingkat pendidikan, pengalaman berorganisasi, latar belakang sosial, partisipasi dalam partai politik, prestasi serta hal-hal yang terkait dengan kapabilitas, akseptabiltas, serta popularitas dari caleg, meski setiap partai memiliki cara dan mekanisme tersendiri untuk merebut suara pemilih.

c. Implementasi kuota $30 \%$ keterwakilan perempuan pada setiap partai politik ternyata mengalami banyak kendala, seperti 
Sofia Hardani: Komitmen Partai Politik Terhadap Pencalonan Perempuan sebagai Anggota Legislatif dalam Upaya Realisasi Undang-undang No.122 Th.2003 di Pekanbaru

kurangnya calon legislatif perempuan yang berkualitas, kurangnya pimpinan partai dalam melaksanakan ketentuan pasal 65 ayat 1 UU No. 12 tahun 2003, dan tidak adanya kebijakan khusus partai politik dalam menjawab apa yang dipersyaratkan undangundang tersebut. Disamping itu juga dirasakan mepetnya waku yang teralokasi bagi pimpinan partai politik dalam menjaring sebanyak mungkin calon legislatif perempuan. Meskipun demikian, ketentuan pasal 65 ayat 1 ini tetap menjadi perhatian dari beberapa partai politik peserta pemilu, seperti Partai Golkar, Partai Amanat Nasional, dan Partai Keadila Sejahtera.

Meskipun pasal 65 ayat $1 \mathrm{UU}$ No. 12 tahun 2003 mengemukakan bahwa setiap partai politik peserta pemilu dapat mengajukan calon anggota DPR,DPRD Provinsi danDPRD Kabupaten/Kota untuk setiap daerah pemilihan dengan memperhatikan keterwakilan perempuan sekurangkurangnya $30 \%$, namun pasal ini tidak menjelaskan secara tegas sanksi yang dikenakan terhadap partai politik yang tidak melaksanakan ketentuan undang-undang ini. Akibatnya segala sesuatu terpulang kepada kebijakan partai dalam mengimplementasikan pasal 65 ayat 1 No. 12 tahun 2003 tersebut.
Secara umum, dari 24 partai politik yang mengajukan calon legislatif ke KPUD Kota Pekanbaru, terdapat 12 partai politik $(50 \%)$ yang telah mengimplementasikan pasal tersebut, sementara sisanya sangat variatif dan tidak memenuhi kuota $30 \%$. Partai politik yang memenuhi kuota $30 \%$ tersebut adalah partai-partai politik yang besar, seperti Partai Golkar, Partai Demokrat, Partai Keadilan Sejahtera, dan Partai Amanat Nasional. Diantara kempat partai tersebut, satu partai justru melebihi kuota yang disyaratkan oleh undang-undang, yaitu Partai Keadilan Sejahtera. Dari 45 caleg yang diajukan partai ini untuk diverifikasi oleh KPU Kota Pekanbaru, keterwakilan perempuan berjumlah $38 \%$ (17 orang). ${ }^{11}$

Terkait upaya partai politik untuk memenuhi ketentuan kuota $30 \%$ keterwakilan perempuan ini, KPUD Pekanbaru telah melakukan pengembalian berkas pengajuan calon legislatif kepada partai-partai yang belum memenuhinya, akan tetapi partai politik tetap saja mengajukan berkas yang sama karena kurangnya perempuan yang mengajukan diri menjadi caleg. Hal ini terindikasi dari apa yang diungkapkan oleh Ketua KPUD Kota Pekanbaru berikut:"Kuota 30\% sepertinya tidak diperhatikan oleh pimpinan parpol, dan walaupun KPUD sudah mensosialisasikannya kepada pimpinan parpol, namun parpol tersebut tidak menyampaikan kepada anggotanya. 
Yang lebih unik lagi pada waktu penjaringan dijanjikan nomor urut pertama atau kedua, tapi setelah di KPUD pimpinan parpol mengumumkan yang berlainan dengan janjinya. Hal ini tentunya menimbulkan kekecewaan di pihak caleg perempuan."

Terlebih lagi, pasal 67 ayat 1 UU No. 12 tahun 2003 menyebutkan bahwa: "urutan nama calon anggota DPR, DPRD Provinsi, DPRD Kabupaten/ Kota untuk setiap daerah pemilihan disusun oleh KPU Provinsi, KPU Kabupaten dan Kota, berdasarkan nomor urut jadi yang ditetapkan partai politik peserta pemilu sesuai dengan tingkatannya."

Dari pasal ini dipahami bahwa segala sesuatunya terletak di tangan partai dalam menentukan kebijakan mengenai nomor urut. Berdasarkan hasil penelitian, ternyata dari tiga parpol besar yang dijadikan sampel, hanya PAN yang memberlakukan suatu kebijakan khusus dalam rangka mensupport kuota $30 \%$ keterwakilan perempuan dalam legislatif. Pada waktu seleksi, PAN memberikan keistimewaan kepada caleg perempuan apabila scoring yang didapatkannya sama dengan laki-laki, maka caleg perempuanlah yang diberikan prioritas. Kebijaan ini ternyata tidak ditemui pada partai lainnya.

Dengan sikap politik masingmasing partai politik yang mengikuti pemilu legislatif tahun 2014, dari sejumlah 45 orang calon anggota legislatif yang lolos seleksi, terdapat 9 orang perempuan, dan laki-laki 36 orang. Hal tersebut dapat dilihat pada table berikut sesuai dengan Daerah Pemilihan (Dapil) masing-masing caleg.:12

Tabel 1: Anggota DPRD Riau tahun 2014-2019 menurut Daerah Pemilihan

\begin{tabular}{|l|l|l|l|l|l|}
\hline $\begin{array}{c}\text { No } \\
\cdot\end{array}$ & \multicolumn{1}{|c|}{ Nama } & $\begin{array}{c}\text { Jenis } \\
\text { Kelamin }\end{array}$ & & \multicolumn{1}{|c|}{ Partai } & \multicolumn{1}{c|}{$\begin{array}{l}\text { Daerah } \\
\text { Pemilihan }\end{array}$} \\
\hline 1 & Roni Amriel, SH & Laki-laki & & Golkar & Dapil I \\
\hline 2 & Hj. Masny Ernawati & & Perempuan & Golkar & Dapil II \\
\hline 3 & Sahril, SH & Laki-laki & & Golkar & Dapil III \\
\hline 4 & Tarmizi M & Laki-laki & & Golkar & Dapil IV \\
\hline 5 & Hj Syarly Yulian & & Perempuan & Golkar & Dapil IV \\
\hline 6 & Yose Saputra & Laki-laki & & Golkar & Dapil V \\
\hline 7 & Ida Yulita Susandi, SH & & Perempuan & Golkar & Dapil V \\
\hline 8 & Eri Sumarni & & Perempuan & Demokrat & Dapil I \\
\hline 9 & Aidil Amri & Laki-laki & & Demokrat & Dapil II \\
\hline 10 & Heri Setiawan & Laki-laki & & Demokrat & Dapil III \\
\hline 11 & T. Aswendi & Laki-laki & & Demokrat & Dapil IV \\
\hline 12 & Sigit Yuwono, ST & Laki-laki & & Demokrat & Dapil V \\
\hline
\end{tabular}


Sofia Hardani: Komitmen Partai Politik Terhadap Pencalonan Perempuan sebagai Anggota Legislatif dalam Upaya Realisasi Undang-undang No.122 Th.2003 di Pekanbaru

\begin{tabular}{|c|c|c|c|c|c|}
\hline 13 & Desi Susanti, S.Sos & & Perempuan & Demokrat & Dapil V \\
\hline 14 & Rustam Panjaitan & Laki-laki & & PDIP & Dapil I \\
\hline 15 & Dapot Sinaga, SE & Laki-laki & & PDIP & Dapil II \\
\hline 16 & Roslan Tarigan & Laki-laki & & PDIP & Dapil III \\
\hline 17 & Hotman Sitompul & Laki-laki & & PDIP & Dapil IV \\
\hline 18 & Jhon Romi Sinaga & Laki-laki & & PDIP & Dapil V \\
\hline 19 & H. Fathullah & Laki-laki & & Gerindra & Dapil I \\
\hline \multirow[t]{2}{*}{20} & H. Wan Agusti & Laki-laki & & Gerindra & Dapil II \\
\hline & - & - & & Gerindra & Dapil III \\
\hline 21 & Sri Rubianti & & Perempuan & Gerindra & Dapil IV \\
\hline 22 & Zainal Arifin, SE & Laki-laki & & Gerindra & Dapil V \\
\hline \multirow[t]{2}{*}{23} & Darnil & Laki-laki & & Hanura & Dapil I \\
\hline & - & - & & Hanura & Dapil II \\
\hline 24 & Kudus Kurniawan Siahan, S.Is & Laki-laki & & Hanura & Dapil III \\
\hline 25 & Ali Suseno & Laki-laki & & Hanura & Dapil IV \\
\hline 26 & Ferry Shandra Pardede, SE & Laki-laki & & Hanura & Dapil V \\
\hline 27 & Ir. Nofrizal, MM & Laki-laki & & PAN & Dapil I \\
\hline 28 & Puji Daryanto & Laki-laki & & PAN & Dapil II \\
\hline 29 & Maspendri & Laki-laki & & PAN & Dapil III \\
\hline 30 & Sondia Warman & Laki-laki & & PAN & Dapil IV \\
\hline 31 & Hj. Yurni & & Perempuan & PAN & Dapil V \\
\hline \multirow[t]{3}{*}{32} & Tarmizi Akhmad & Laki-laki & & Nasdem & Dapil I \\
\hline & - & & & Nasdem & Dapil II \\
\hline & - & & & Nasdem & Dapil III \\
\hline 33 & Fikri Wahyudi & Laki-laki & & Nasdem & Dapil IV \\
\hline 34 & Zulfan Hafiz, ST & Laki-laki & & Nasdem & Dapil V \\
\hline \multirow[t]{2}{*}{35} & Yusrizal & Laki-laki & & PKB & Dapil I \\
\hline & - & & & PKB & Dapil II \\
\hline 36 & H. Marlis Kasim & Laki-laki & & PKB & Dapil III \\
\hline 37 & Zaidir Albaiza & Laki-laki & & PKB & Dapil IV \\
\hline 38 & Suprianto & Laki-laki & & PKB & Dapil V \\
\hline \multirow[t]{3}{*}{39} & Roem Diani Dewi, SE, MM & & Perempuan & PKS & Dapil I \\
\hline & - & & & PKS & Dapil II \\
\hline & - & & & PKS & Dapil III \\
\hline 40 & Dian Sukheri & Laki-laki & & PKS & Dapil IV \\
\hline \multirow[t]{2}{*}{41} & Mulyadi, Amd & Laki-laki & & PKS & Dapil V \\
\hline & - & - & - & PPP & Dapil I \\
\hline 42 & Samsul Bahri, S.Pd & Laki-laki & & PPP & Dapil II \\
\hline 43 & Said Usman Abdullah & Laki-laki & & PPP & Dapil III \\
\hline 44 & Zulkarnain & Laki-laki & & PPP & Dapil IV \\
\hline 45 & Drs. Nasruddin Nasution, MA & Laki-laki & & PPP & Dapil V \\
\hline
\end{tabular}

Sumber : diolah dari data KPUD Prov. Riau 2014 
Untuk lebih jelasnya, jumlah caleg yang lulus seleksi 2014-2019 berdasarkan jenis sebagai anggota DPRD Riau tahun kelamin adalah sebagai table berikut.

Tabel 2: Anggota DPRD Riau tahun 2014-2019 Menurut Jenis Kelamin

\begin{tabular}{|c|c|c|c|c}
\hline No & Nama Partai & Laki-laki & Perempuan & Jumlah \\
\hline 1 & Golkar & 4 & 3 & 7 \\
\hline 2 & Demokrat & 4 & 2 & 6 \\
\hline 3 & PDIP & 5 & - & 5 \\
\hline 4 & Gerindra & 4 & 1 & 4 \\
\hline 5 & Hanura & 4 & - & 4 \\
\hline 6 & PAN & 3 & - & 5 \\
\hline 7 & Nasdem & 4 & - & 3 \\
\hline 8 & PKB & 2 & 1 & 3 \\
\hline 9 & PKS & 37 & - & 4 \\
\hline 10 & PPP & & & 45 \\
\hline & Jumlah & 4 & \\
\hline
\end{tabular}

Dari tabel diatas diketahui bahwa caleg perempuan yang lulus seleksi menjadi anggota legislatif berjumlah 8 orang, yang berasal dari; partai Golkar 3 orang, Demokrat 2 orang, Gerindra 1 orang, PAN 1 orang, PKS 1 orang. Sementara partai lainnya seperti PDIP yang menduduki 5 kursi di legislatif, semuanya adalah laki-laki. Demikian juga Hanura, PKB, dan PPP, yang masing-masingnya memperoleh empat kursi, semuanya diduduki oleh laki-laki. Yang menarik adalah PKS, dari 3 kursi yang dimenangkan, 1 diduduki oleh perempuan, sementara untuk laki-laki ada dua kursi.

Secara keseluruhan, quota $30 \%$ yang diamanatkan oleh undangundang no. 12 tahun 2003 untuk perempuan belumlah terpenuhi menurut data diatas. Ada beberapa partai yang caleg perempuannya tidak lolos dalam pemilihan anggota legislatif provinsi Riau periode 2014-2019, yaitu partai PDIP, Hanura, Nasdem, PKB, dan PPP. Akan tetapi ada partai yang justru caleg perempuannya memperoleh kursi melebihi kuota yang ditetapkan undang-undang, yaitu PKS. Dari tiga calegnya yang lolos, dua diantaranya adalah perempuan. Prestasi yang dicapai PKS ini tidak terlepas dari usaha dan kemampuan para caleg perempuannya. Umpanya seperti "barter politik" yang dilakukan oleh salah seorang caleg perempuan PKS. Barter politik yang dilakukan cukup sederhana, yaitu saling mendukung, 
saling bantu dalam mempromosikan diri dengan rekan caleg perempuan dari partai lain. ${ }^{13}$ Selain itu, prestasi PKS tersebut juga sangat ditentukan oleh banyaknya jumlah aktifis perempuan di PKS yang mempunyai pegalaman berorgansasi yang baik.

\section{Analisis Data Penelitian}

Tidak lagi menjadi perdebatan "panas" bahwa keterlibatan perempuan dalam dunia politik dari perspektif Islam adalah sama dengan laki-laki dalam rangka amr ma'ruf nahiy munkar. Berpolitik dengan dilandasi etika dan nilai Islam adalah suatu bentuk ibadah. Oleh karena itu, keikutsertaan perempuan dalam parlemen dibolehkan karena parlemen dipandang sebagai salah satu sarana untuk $a m r$ ma'ruf nahiy munkar terhadap pelaksanaan negara dan pemerintahan demi kepentingan umat. Pandangan seperti itu dianut oleh partai-partai politik, khususnya yang berafiliasi Islam di Indonesia.

Proses seleksi calon anggota legislatif pada hakikatnya dikenal dengan istilah rekrutmen politik. Dalam politik modern proses rekrutmen terus terbuka bagi setiap orang tanpa membedakan jenis kelamin, suku atau atribut lainnya. Yang menjadi penentu utama dalam perekrutan seseorang terletak pada kapabilitas, akseptabilitas dan popularitas seseorang. Adapun faktor-faktor yang mendukung seseorang untuk duduk dalam suatu jabatan public diantaranya adalah karakteristik latar belakang sosial, sosialisasi politik yang dialami, aktifitas awal dan magang serta motivasi dan seleksi.

Dalam melakukan rekrutmen anggota yang diproyeksikan menjadi kader partai hendaklah menggunakan persyaratan yang memuat ketentuan umum mengenai tingkatan atau jenjang organisasi kepartaian yang dikaitkan dengan orbitasi atau promosi kader partai. Misalnya bagi seseorang yang belum pernah berhasil mewakili kecamatan di tingkat kabupaten atau kota tidak bisa direkrut untuk calon pada kedudukan di level yang lebih tinggi (level provinsi).

Temuan penelitian menunjukkan adanya fenomena "separo hati" dari pimpinan partai untuk mengimplementasikan pasal 65 ayat $1 \mathrm{UU}$ No. 12 tahun 2003. Hal ini dibuktikan tidak ada satupun partai yang membuat kebijakan khusus secara formal dalam proses penjaringan dan penyaringan caleg, terutama untuk perempuan. Kalaupun PAN lebih memilih caleg perempuan untuk diajukan, itupun terjadi jika skor yang diperoleh caleg perempuan sama dengan caleg laki-laki. Jadi, bukan karena adanya kebijakan khusus yang dituangkan secara formal dalam bentuk keputusan partai.

Disamping kebijakan yang tidak responsif jender, pemahaman 
keterwakilan perempuan juga satu hal yang dipertanyakan. Dalam hal ini kebanyakan pemimpin partai masih tetap memandang perempuan sebagai "warga negara kelas dua" yang belum pantas untuk duduk di nomor urut pertama mewakili partainya. Kenyataan ini didukung oleh pendapat ketua KPUD Pekanbaru sebagai berikut ini:

"Banyak perempuan yang mengundurkan diri menjadi caleg karena merasa terkecoh oleh pimpinan partai dalam menyusun nomor urut caleg.Waktu pengisian formulir, pimpinan partai sengaja mengosongkan nomor urut caleg dan hanya menjanjikan secara lisan kepada perempuan untuk ditempatkan di nomor urut jadi.Tapi setelah di KPUD ternyata mereka diletakkan di nomor urut yang tidak menjanjikan, atau malah ditempatlan di nomor urut pertama tetapi tidak pada daerah basis massanya, sehingga tidak terpilih."

Kenyataan ini sebenarnya tidak sepenuhnya merupakan kesalahan pimpinan partai, tetapi juga terletak pada perempuan itu sendiri yang tidak memahami hak dan kewajibannya dalam mengisi dan melengkapi persyaratan proses seleksi calon, terutama dalam kaitannya dengan nomor urut caleg. Pemahaman seseorang terhadap suatu proses pencalonan dipengaruhi oleh banyak faktor, diantaranya pengetahuan tentang politik yang juga terkait dengan tingat pendidikan, pengalaman berorganisasi serta motivasi diri untuk menduduki jabatan politik itu sendiri.

Terlepas dari implementasi kuota 30\% keterwakilan perempuan, disadari atau tidak banyak hambatan yang ditemui oleh perempuan untuk berkiprah di dunia politik, seperti budaya patriarkhi, kultur dan sistem politik yang tidak menguntungkan posisi perempuan, sampai kepada aspek internal perempuan itu sendiri. Untuk itu diperlukan beberapa langkah kongkrit bagi peningkatan partisipasi politik perempuan pasca kuota, yaitu: Pertama, perempuan yang terjun ke dunia politik harus terlebih dahulu membekali dirinya dengan kapasitas tertentu, seperti pengetahuan, pengalaman, dana yang cukup, serta tersosialisasi dalam politik dalam jangka waktu panjang sehingga dapat dilihat kredibilitas dan akseptabilitasnya di tengah-tengah massa pemilih. Kedua, partai politik sebagai institusi penerima instruksi program affirmative actionhendaknya mampu menyiapkan kader perempuan yang layak dinominasikan, ataupun kader perempuan yang pantas untuk duduk sebagai pengurus partai. Ketiga, menciptakan aliansi lintas partai yang memiliki kesamaan perhatian atas isu keadilan dan kesetaraan gender dalam bidang politik. Keempat, perempuan harus senantiasa membentuk ikatan dan 
memelihara kontak dengan media massa. Kelima, membangun jaringan yang erat dengan masyarakat sipil dan organisasi kepentingan tertentu, LSM, para akademisi, dan sebagainya, agar bersama-sama mengawasi pelaksanaan sistem kuota. Keenam, secara konsisten membangun jaringan dengan para pemilih sekaligus mendengarkan kesulitan dan tuntutan mereka, kemudian membangun tanggapan legislatif atas hal-hal diatas.

Dengan adanya upaya diatas, diharapkan affirmative action melalui kuota dapat dijadikan langkah awal bagi peningkatan partisipasi politik perempuan. Dengan kata lain, pasca kuota perempuan tentunya harus berjuang lebih serius dalam memberdayakan diri semaksimal mungkin, guna berhadapan dengan laki-laki dalam menghadapi jabatan publik.

\section{KESIMPULAN}

Seleksi calon anggota legislatif yang dilakukan oleh partai politik memiliki mekanisme yang sangat tergantung pada kebijakan partai politik itu sendiri dengan indikator yang relatif sama seperti tingkat pendidikan, pengalaman berorganisasi, latar belakang sosial, partisipasi dalam partai politik, prestasi serta hal-hal terkait dengan kapabilitas, akseptabilitas, serta popularitas dari caleg. Sementara pelaksanaan hal tersebut ternyata mengalami banyak kendala, seperti kurangnya calon perempan yang berkualitas, kurangnya pimpinan partai dalam melaksanakan ketentuan pasal 65 ayat 1 UU No. 12 tahun 2003, dan tidak adanya kebijakan khusus partai politik dalam menjawab apa yang dipersyaratkan UU tersebut.

\section{Endnotes:}

1 Gabriel A. Almond and James S. Coleman, The Politics of Developing Areas, (New Jersey: Princeton University Press, 1960) dalam Sudjiono Sastroatmojo, Prilaku Politik, (Semarang: IKIP Semarang Press, 1995), hal. 115

2 Sebagai gambaran dan alasan pentingnya keterlibatan perempuan di lembaga legislatif, dapat disimak sebuah penelitian yang dilakukan Hege Skjeie pada parlemen Norwegia, dimana lebih $40 \%$ anggotanya adalah perempuan.Hasil penelitian menemukan empat hal penting; pertama, bahwa memasukkan perempuan kedalam partai politik telah mengubah sudut pandang partai, lebih konkrit mengubah agenda partai; kedua, memasukkan perempuan dalam politik tidak menghasilkan wilayah perhatian yang tumpang tindih.Artinya, perempuan mempunyai kepentingan dan sudut pandang politik yang berbeda dengan laki-laki; ketiga, wilayah perhatian politisi perempuan lebih dominan pada bidang sosial dan kesejahteraan, perlindungan lingkungan, perlucutan senjata, kebijakan kesetaraan, pendidikan dan kesehatan. Sementara perhatian politisi laki-laki lebih besar pada bidang ekonomi, transportasi, isu-isu energi, keamanan nasional, industri dan luar negeri; keempat, wilayah kebijakan yang memperlihatkan pengaruh perempuan paling dominan adalah pada politik perlindungan secara bertahap yang ditujukan pada tanggungjawab negara untuk memberikan kesempatan kepada perempuan menggabungkan kewajiban keibuan (motherhood) dengan hak kemerdekaan ekonomi. Hasil konkritnya adalah meningkatnya anggaran publik untuk pembiayaan perawatan anak-anak, pemilihan waktu kerja yang lebih lentur lewat penganggaran kerja/waktu, perluasan cuti orang tua dan menjamin hak ayah berbagi periode cuti, dan juga hak pensiun bagi pelayanan kerja yang tidak diupah. Mencermati apa yang telah dihasilkan oleh perempuan dalam parlemen Norwegia, ternyata berdampak sangat signifikan pada tingkat kesejahteraan masyarakat disana. 
Norwegia adalah salah satu negara-negara Skandinavia yang memiliki pelayanan publik sangat baik, bahkan terbaik di dunia.https:// sites.google.com/site/wdcbandaceh/home/ perempuan-ranah-politik

3 Saat ini jumlah perempuan di MPR-RI 13\%, di DPR-RI 11\%, di DPD-RI 21\%, di DPR Provinsi 9 $\%$ (di Banten hanya 6,7\% atau lima orang dari 75 anggota), dan di DPR Kabupaten/Kota sekitar 5\% (banyak Kab./Kota yang anggotanya 100\% lakilaki). Lihat http://www.radarbanten.com/ mod.php? $\bmod =$ publisher\&op=viewarticle \&artid=12398

4 Ketertinggalan perempuan tidak hanya di lembaga legislatif sebagai wakil rakyat yang 'dipilih', tetapi juga di ranah eksekutif dan yudikatif sebagai pejabat publik yang 'ditunjuk'. Dalam lembaga eksekutif, jumlah pejabat struktural (PNS) perempuan di Eselon I hanya 10\%, Eselon II 6\%, Eselon III 12,70\%, dan Eselon IV 22,05\%. Sementara di lembaga yudikatif sedikit lebih banyak, perempuan pejabat negara di instansi peradilan/Hakim berjumlah 24,09\% dan di lembaga penuntut umum/Jaksa 26,75\%.

5 M.Q. Patton, Qualitative Evaluation and Research Method, (Newbury Park : Sage Publication, 1990)

6 Mattew Miles dan A. Michael Huberman, Analisa Data Kualitatif.Terjemahan oleh Tjetjep Rohindi Rohidi.Jakarta : UI Press,1992.

7 K. Ramanathan,Konsep Azas politik,Jakarta: ALMS Digital Enterprise, 2000, hal. 167

8 Miriam Budiardjo,Partisipasi dan Partai Politik, Jakarta: Buku Obor, 1998, hal. 16

9 Miriam Budiardjo, Dasar-Dasar Ilmu Politik Edisi Revisi, Jakarta: PT Gramedia PustakaUtama, 2008, hal. 404

10 Hege Skjeie melakukan penelitian pada parlemen Norwegia, dimana lebih $40 \%$ anggotanya adalah perempuan.Hasil kerja perempuan dalam parlemen Norwegia, ternyata berdampak sangat signifikan pada tingkat kesejahteraan masyarakat disana. Norwegia adalah salah satu negaranegara Skandinavia yang memiliki pelayanan publik sangat baik, bahkan terbaik di dunia.https://sites.google.com/site/ wdcbandaceh/home/perempuan-ranah-politik

11 Syamsuddin B, Ketua DPD PKS Kota Pekanbaru, wawancara 15 April 2014), Pekanbaru.Informasi diatas dibenarkan oleh Fahri Yassin, anggota KPU Kota Pekanbaru, wawancara 22 April 2014, Pekanbaru.

12 Pemilihan anggota legislatif di Pekanbaru dibagi kepada lima Daerah Pemilihan (Dapil), yaitu: Dapil I terdiri dari Kecamatan Sukajadi, Pekanbaru Kota, Limapuluh dan Senapelan; Dapil II terdiri dari Kec. Rumbai dan Rumbai Pesisir; Dapil III terdiri dari Kec. Sail dan Tenanyan Raya; Dapil IV terdiri dari Marpoyan Damai dan Bukit Raya; dan Dapil V adalah
Kecamatan Tampan dan Payung Sekaki.

13 Hayatun Nufus, S.Pt., Caleg Dapil 4 DPRD Kota Pekanbaru, No. Urut 8 dari PKS, wawancara, 26 Juni 2014, Pekanbaru.

\section{DAFTAR PUSTAKA}

Alwi, Aidit dan Zainal AKSP, (eds.). (1989). Elite dan Modernisasi. Yogyakarta: Liberty.

Gaffar, Afan. (1991). “Demokrasi Empiris dalam Era Orde Baru" dalam Alfian dan Nazarudin Sjamsuddin (eds.). Budaya Politik Indonesia. Jakarta : Grafitti.

Haryanto. (1997). Sistem Politik : Suatu Pengantar. Yogyakarta : Liberty.

Imawan, Riswandha. (1992). Proses Pencalonan dan Calon dalam Pemilu 1992. Makalah disampaikan dalam Seminar Nasional IX, Asosiasi Ilmu Politik Indonesia, Surabaya, Agustus 1992.

La Palombara, Joseph. (1974). Political Participation and Behavior. New Jersey : Prentice HalI Inc.

Mas'oed, Mohtar dan Collin
MacAndrews (ed.). (1978).
Perbandingan Sistem Politik.
Yogyakarta : Gadjah Mada
University Press.

Miles, Matthew B \& A. Michael 
Sofia Hardani: Komitmen Partai Politik Terhadap Pencalonan Perempuan sebagai Anggota Legislatif dalam Upaya Realisasi Undang-undang No.122 Th.2003 di Pekanbaru

Huberman. (1992). Analisa Data Kualitatif. Terjemahan oleh Tjetjep Rohindi Rohidi. Jakarta:UI Press.

Patton, M.Q. (1990). Qualitative Evaluation and Research Method. Newbury Park:Sage Publication.

Sadli, Saparinah. (2004). "Perempuan Hanya Dijadikan Vote Getter Oleh Partai Politik" dalam Harian Media Indonesia. 2 Februari 2004.

Suyanto, Isbodroini. (2003). Kesiapan

Perempuan Menghadapi Pemilu 2004. Makalah disampaikan dalam Seminar Nasional AIPI di Bukittinggi.

Undang-undang No.12 Tahun 2003 tentang Pemilihan Umum.

Andriani S. Soemantri Sebagai Gender Specialist BAPPENAS, Pedoman Pengurusutamaan Gender Dalam Menanggulangi KEmiskinan, 2004

BPS, Jumlah Keterwakilan Perempuan Pengambil Keputusan Politik di Indonesia, Jakarta: BPS, 2000

Divisi Perempuan,Pentingkah Perempuan Duduk Dalam Lembaga Politik, Centre For Electoral Reform, 2004

Gabriel A. Almond and James S. Coleman, The Politics of
Developing Areas, (New Jersey: Princeton University Press, 1960) dalam Sudjiono Sastroatmojo, Prilaku Politik, (Semarang: IKIP Semarang Press, 1995)

Kementrian Negara Pemberdayaan Perempuan, Jurnal Pemberdayaan Perempuan, Vol. 7 No. 2 Desember 2007

Lely Zailani, Perempuan dan Politik, http:/www.berpolitik.com

Mansour Fakih, Analisis Gender dan Transpormasi Soisal, Yokyakarta: Pustaka Pelajar, 1997

Michael Rush dan Philip Althoff, Pengantar Sosiologi Politik, Jakarta: Grafindo Persada, 1993

Miriam Budiarjo, Dasar-dasar Ilmu Politik, Jakarta: PT. Gramedia Pustaka Utama, 1992

Muhajir M. Darwin, Negara dan Perempuan Reorientasi Kebijakan Publik, Yokyakarta: Graha Guru, 2005

Nurhidayah, "Partisipasi Politik Anggota Legislatif Perempuan dalam Pengambilan Kebijakan," dalam Journal of Educational Sosial Studies, http://journal.unnes. ac.id/sju/index.php/jess. 